\title{
Introduction: Moralities of Warfare and Religion"
}

\author{
Angela Kallhoff / Thomas Schulte-Umberg
}

Since antiquity, war has been at the center of moral reasoning. The moral questions involved can either be considered as part of the law of nations or as "just war theory". The latter can be traced back to the ancient Greeks, Cicero, and Augustine, the former to the Early Modern Age. Francisco Suárez and Hugo Grotius are regarded as first seminal proponents of a law of nations that includes war activities. In all these discussions, war was sometimes seen as a necessary political instrument, yet even more so as a malady. Albeit deeply rooted in human nature and the state of human society, it had to be justified and, if it proved to be inevitable, to be ordered and its consequences needed to be restricted. But the proposal that the use of force in interstate relations should be strictly prohibited was not discussed in terms of public policy before the end of World War I (WWI).

In the Kellogg-Briand Pact of 1928 (officially: Generally Treaty of Renunciation of War as an Instrument of National Policy), the signatory states promised not to use war to resolve "disputes or conflicts of whatever nature or of whatever origin they may be, which may arise among them". ${ }^{1}$ By 1929, 54 states had signed the Pact, among them the major belligerent nations of WWI with the notable exception of Japan. Even with due regard being given to the ineffectiveness of the pact in the following decades, the central ideas renouncing the use of war, the promotion of peaceful settlements of disputes, and the use of collective force to

* The first seven papers collected in this volume were delivered at two conferences in Vienna in spring 2014 and spring 2016. The conferences were thankfully funded by the Institute for Philosophy and the Faculty of Catholic Theology of the University of Vienna, furthermore by "Wien Kultur", a Department of the City of Vienna. An additional paper was invited, three more go back to a call for papers in early 2017. Our thanks go to all contributors, their readiness to participate and their endurance. We would also like to thank the anonymous reviewers which contributed in essential ways to the content of this volume. A special thanks goes to the main editors of the journal and their willingness to dedicate one volume to the "Moralities of Warfare". Finally we would like to thank the staff of the journal, Jakob Deibl and especially Daniel Kuran, for all their work and diligence.

1 For the text of the pact, also called Paris-Pact, see: history.ubc.ca/sites/default/files/ courses/documents/[realname]/kellogg-briand_pact_1928_0.pdf accessed March 122018. See also Oona A. Hathaway / Scott J. Shapiro, The Internationalists: How a Radical Plan to Outlaw War Remade the World, New York 2017. 
Angela Kallhoff / Thomas Schulte-Umberg

prevent aggression proved to be a legal and moral basis to outlaw war. Most prominently, they were incorporated in the United Nations Charter (1945).

From that perspective, war, and also peace, were not only interpreted as interstate conflicts, but they were also interpreted as an intensely hierarchical activity; namely, war is reasoned and organized from above, while simultaneously being executed from below. Formulations of the theory of war, be they religious or secular, have maintained and even reinforced that interpretation until today. The ways in which a given authority applied its power to declare and wage war are a unilateral exercise of power from above. Even the ideals of individual citizenship and popular sovereignty didn't change that. An example in case is the political writing of Rousseau. He tried to reconcile obedience and freedom by making each citizen the author as well as the subject of political power: "each, joining together with all, may nevertheless obey himself, and remain as free as before." 2 Defending la patrie during the French Revolution was considered to be the citizen's superior duty to the collective. Concepts of class, manifest destiny, race or Volk even provided a stimulating power for the mobilization of people as never seen before. In that framework, combatants and noncombatants are pure instruments of warfare. Obeying war-waging authorities, so people were told, was in a sense the same as to obey oneself, since citizens made up the collective to which they belonged and whose destiny they had to share.

The ideal of a higher entity demanding absolute obedience has never been considered justified from the perspective of a moral theory of war during the $20^{\text {th }}$ century. Even the Nazi war of extermination was somewhat waged assuming that it was necessary to override some basic elements of the just conduct of war. From a historical perspective, it also still needs to be explained in which ways the presumption of the moral responsibility of individual combatants gained ground after 1945. The crimes committed during World War II played a role. And later developments such as the cultural, political, and social upheavals of the 1960s appear to have been an important ingredient in that development as well. Since then, soldiers could, to a certain extent, be held responsible for their deeds in legal and moral ways. Yet, historical evidence also contributes to the insight that its acceptance and its implementation are far from completed. To give an example, the US soldiers perpetrating the massacre of My Lai in March 1968 broke and disregarded rules of conduct that each American soldier serving in Vietnam received on pocket cards in 1967. ${ }^{3}$ The massacre became publicly known in 1969 and increased the public's opposition to the war. Nevertheless, only some of the officers who committed war crimes were charged, and only one of them was con-

2 Jean Jacques Rousseau, The Social Contract, and the First and Second Discourses, ed. by Susan Dunn, with essays by Gita May et. Al., New Haven 2002, p. 163.

3 See the "Nine Rules [of Conduct]" Card. Source: http://amhistory.si.edu/military history/collection/object.asp $? \mathrm{ID}=126 \&$ ImageID $=744 \&$ printable $=0 \&$ back $=1 \quad$ (accessed March 10 2018). 
victed. Another example of the still problematic nature of moral judgment on fulfilling one's duty in wartime is a statement given by a Military Chaplain with regard to the Upper-Austrian conscientious objector, Franz Jägerstätter. The latter refused to serve in the German Wehrmacht on religious and moral grounds. He was sentenced to death in 1943. In 2007, the year of Jägerstätter's beatification, the chaplain called him in a somewhat self-defeating statement "a pitiable victim of his erring conscience, which today - in some embarrassingly touching ways - is politically instrumentalized". "These examples demonstrate the existing gap between a tentative moral assessment of soldiers' actions in fighting a war, on the one hand, and the still hesitant commitment to moral and legal rules of a war ethics on the other.

The rather late perspective on the outlawry of war in human history and a recent focus on the morale of combatants and non-combatants necessitate a deeper assessment of moral motives in war. In our view, research on commitment to war and an inquiry into motives and reasons in fighting a war need to be accomplished by a more comprehensive reconstruction of the formation, fixation and also the disintegration of the interpretive appropriation of war. This volume is dedicated to investigating this perspective of war, in particular with regard to the combatants. It presents original research on war theory and war ethics given by authors from a broad range of disciplinary training, including history, theology, literary studies, philosophy, and sociology. In focusing on soldiers and their commitments in war from these various perspectives, this volume presents new insights into war theory from a still unusual perspective. It focuses on "war morale," which frames and interprets the actions of soldiers and non-combatants in war.

Such an inquiry also includes a deeper examination of the actions of various war participants. The hope is that this might also lead to some new perspectives for the enhancement of peace. Reports on war experiences have always had the capacity to call the sense of a given war into question, possibly even of war itself. A case in example is given by a recent reassessment of war ethics by the philosopher Nancy Sherman. ${ }^{5}$ She also explores the personal assessments of former soldiers in the United States, and in particular the view of veterans. She claims that, in order to overcome war traumata, it is particularly important for veterans to regard their own fight as part of an endeavor that was overall a "just war," or at least a particularly worthwhile enterprise at that time. In this light, Sherman comments on the reports given by her father, himself a war veteran:

4 Christian Feldmann, "Ein Martyrium mit Folgen. Die Seligsprechung des Wehrdienstverweigeres Franz Jägerstätter fiel der katholischen Kirche nicht leicht", 28.10.2007, source: zeit.de/2007/44/Jaegerstaetter/komplettansicht, (accessed March 12 2018).

5 Nancy Sherman, Afterwar: Healing the Moral Wounds of Our Soldiers, Oxford; New York 2015. 
Angela Kallhoff / Thomas Schulte-Umberg

In his case, he does have time to reflect, and wonders if the fight is worth the horrific ruin and devastation he anticipates and then sees up close in dying men and mutilated bodies. That sense of his own responsibility for the specific war he fights is there, whether he talks about it openly or not. The worry is about proportionality, the ratio of the good anticipated to all the carnage. Is it worth it? In the war he fought, he believes it was, then and now, as most do. But the point I am making is that the moral oversight is internal. Yes, it is not just about what he did as an individual soldier, in his case, administering inoculations and relief to the war-torn and maimed. It is also about the war he was in. That frames his perspective and his responsibility. ${ }^{6}$

This report demonstrates that a (former) soldier is confronted with questions about the justness of a war that he had to fight. Even when being in a situation to answer with "yes," veterans experience deep misgivings about the pain and horror the war caused.

In order to give more evidence not only of the deep distress that war experiences cause, but also of the moral issues involved in self-inquiry after war, Jonathan Shay's contribution of post-war experiences from a psychiatrist perspective is also illuminating. Shay addresses human behavior in war in light of a comparison to Homer's Iliad, and especially Achilles, with the current war experiences of American veterans suffering from post-traumatic stress disorder. ${ }^{7}$ As he shows in detail, the shrinking of the social and moral horizon, coping with grief, going berserk, dishonoring the enemy or the soldiers' belief in luck and God's will are common traits of experiencing war in the Iliad, as well as in wars of the $20^{\text {th }}$ century. It is important to follow his advice to listen to the voices of combatants before classifying them. However, Shay also stresses the importance of understanding any army,

ancient or modern, as a social construction defined by shared expectations and values.... All together they form a moral world that most of the participants most of the time regard as legitimate, 'natural' and personally binding. The moral power of an army is so great that it can motivate men to get up out of a trench and step into enemy machine-gun fire. ${ }^{8}$

Of course, that social construction and its fabric can be undermined. This volume does not only add new insights on the war morale and the moral framework of war activities with a focus on the soldiers' experiences in war, but it also connects a variety of approaches to frame and to reframe war morale in contemporary sciences with research in theology. Many contemporaries consider today's Christianity as a force that contributes not only to the containment of war, but also to its

6 Ibid., p. 46.

7 Jonathan Shay, Achilles in Vietnam. Combat Trauma and the Undoing of Character, New York 1994.

8 Ibid., p. 6. 
condemnation. ${ }^{9}$ Even if still existing Christian justifications of war are taken into account, the encouragement of troops to fight not only for their fatherland, but also for their God and faith, or blood-thirsty sermons that inspire armies in the name of God seem to be history. They are apparently not forgotten, but truly a thing of the past. Of course, this certainly represents no more than a superficial perspective when considering both the past and the present in a more detailed way, and it is still necessary to add further research to the relationship between faith and war in current research.

Some of the following papers provide detailed insights into the history of the interconnectedness of religion and war, be it with religion at its center or with providing frames of reference for the role of religion and human motivation in war. This view is completed by contributions in this volume that focus on the above-mentioned recent discussions of a moral reassessment of the deeds of combatants in war, including developments after 1945. It also needs to be mentioned that this volume is restricted to Christianity; it does not (for the most part) offer an inquiry into religions other than Christianity. To some degree, this choice is motivated by the view that one might look far too easily at other religions when obliterating the role of Christian faith in the wars of our century. ${ }^{10}$ This volume is also focused on a historical perspective, which comes with the restriction not to inquire into current religiously motivated wars. We nevertheless hope that some lessons from the historical inquiry also add new insights in a broader assessment of religion and war.

We wish to thank the authors of this volume, most of them also contributed to conferences and talks at the University of Vienna on the moralities of warfare in 2014 and 2016. Each scientist contributes a piece of original research. Together, the contributions to this volume offer a detailed and multi-faceted approach to the current debates on the moralities of warfare as related to Christian faith.

9 There is also the viewpoint, of course, that especially monotheistic religions are war promoting in themselves. In the German-speaking countries, there was an intense debate on that topic centered on the work of the Egyptologist Jan Assmann. The basic decision if this is really the case and if Christianity shares this with other religions might be partially considered as redundant. Only the examination of different contexts of experiences through the ages or for longer periods of time will show why and how religion shaped war (and peace).

10 See e.g. the testimony of an American elite soldier, who's reading psalms before and after combat: Rusty Bradley / Kevin Maurer, Lions of Kandahar. The Story of a Fight Against All Odds, New York 2011. More systematic insights provides David Wood, What 've we done. The Moral Injury of our longest Wars, New York 2016. For a war in contemporary Europe see Serhij Zhadan, Warum ich nicht im Netz bin. Gedichte und Prosa aus dem Krieg, transl. from the Ukrainian by Claudia Dathe and Esther Kinsky, Berlin 2016, pp. 11-13. 